\title{
Nitrogen doses in rice grown in a tropical lowland
}

\author{
Marilia Barcelos Souza Lopes, Taynar Coelho de Oliveira, Danilo Pereira Ramos, \\ Leila Paula Tonello, Cassia Mara dos Santos Alexandrino, Rodrigo Ribeiro Fidelis*
}

Federal University of Tocantins, Gurupi, TO, Brazil

*Corresponding author, e-mail: fidelisrr@mail.uft.edu.br

\begin{abstract}
The rice plant is characterized by having high nutrient demand, being nitrogen $(N)$ the main limiting factor to its productivity. The objective of this study was to evaluate the response of two rice cultivars according to doses of nitrogen fertilization. The experiment was carried out in an irrigated lowland area with hydromorphic soil (humic gleysol) at the region of Formoso do Araguaia-TO, Brazil. The experiment design consisted of five $\mathrm{N}$ doses $\left(30,60,90,120\right.$ and $\left.150 \mathrm{~kg} \mathrm{ha}^{-1}\right)$ applied as urea, and two rice cultivars (Irga-424 and Irga-423). Each experimental plot consisted of twenty-seven lines with $15 \mathrm{~m}$ in length, spaced $0.17 \mathrm{~m}$ between rows. The useful plot size was made up of four central lines with two linear meters of length. The evaluated characteristics were plant height, number of panicles per $\mathrm{m}^{2}$, grain yield in $\mathrm{kg} \mathrm{ha}^{-1}$, hundred grain mass in $\mathrm{g}$, nitrogen content in dag $\mathrm{kg}^{-1}$, and total chlorophyll index in CFI. Data were submitted to variance analysis and regression at $5 \%$ probability by F test. The maximum yield was obtained at a dose of 96 and $126.38 \mathrm{~kg} \mathrm{~N} \mathrm{ha}^{-1}$ for Irga424 and Irga-423, respectively. The highest grain yield was 7800 and $5860 \mathrm{~kg} \mathrm{ha}^{-1}$ for Irga-424 and Irga-423, respectively.
\end{abstract}

Keywords: Oryza sativa L., nitrogen, dose, grain yield

\section{Doses de nitrogênio em arroz irrigado cultivado em várzea tropical}

\section{Resumo}

A planta de arroz caracteriza-se por apresentar alta demanda por nutrientes, sendo o nitrogênio o principal fator limitante à sua produtividade. Objetivou-se com este trabalho avaliar a resposta de duas cultivares de arroz irrigado a doses de adubação nitrogenada. O experimento foi realizado em solo Hidromórfico do tipo Gleissolo Húmico de várzea irrigada, na região do Formoso do Araguaia-TO. O arranjo experimental foi constituído por cinco doses de N (30, 60, 90, 120 e $150 \mathrm{~kg}$ $\mathrm{ha}^{-1}$ ) aplicados na forma de uréia, e dois cultivares de arroz (Irga-424 e Irga-423). Cada parcela experimental foi constituída por vinte e sete linhas de $15 \mathrm{~m}$ de comprimento, com espaçamento de $0,17 \mathrm{~m}$ entre linhas. A área útil foi composta pelas quatro linhas centrais no comprimento de dois metros lineares. As características avaliadas foram altura de plantas, número de panículas por $\mathrm{m}^{2}$, produtividade de grãos em $\mathrm{kg} \mathrm{ha}^{-1}$, massa de cem grãos em $\mathrm{g}$, teor de nitrogênio em dag kg-1, em e Índice de clorofila total em ICF. Os dados foram submetidos à análise de variância e de regressão ao nível de $5 \%$ de probabilidade pelo teste F. Maxíma produtividade foi obtida na dose de $96 \mathrm{e}$ $126,38 \mathrm{~kg} \mathrm{ha}^{-1} \mathrm{de} \mathrm{N}$ para Irga-424 e Irga-423, respectivamente. A maior produtividade de grão foi de 7800 e $5860 \mathrm{~kg} \mathrm{ha}^{-1}$ para Irga-424 e Irga-423, respectivamente.

Palavras-chave: Oryza sativa L., nitrogênio, dose, produtividade de grãos 


\section{Introduction}

The rice plant (Oryza sativa L.) is considered the most economic important crop in some developing countries (being the basic food for about 2.5 billion of people), and the increasing consumption imposes on countries the search for new techniques that could increase the production. Due to the increasing consumption, new and more effective crop techniques should be studied to increase productivity, yield and the quality of the harvest product (Cancellier et al., 2011).

Although Brazil presents ideal climate conditions for agriculture, some soil and climate peculiarities indicates that some management recommendations are more efficient when realized on a regional basis. However, it is not possible to find enough studies to allow specific recommendations for all regions of the country. A major limitation is for soils with high sand content, which requires specific fertility management, that are becoming productive due to the suitable use of fertilizers. The state of Tocantins has an area of 27.842.070 $\mathrm{ha}^{-1}$, and $50 \%$ of the area has potential for agricultural production, being the fifth largest rice producer in Brazil (Fidelis et al., 2012).

Nitrogen $(N)$ is the nutrient that is required in more quantity by rice and its application may lead to greater productivity responses. This is because $\mathrm{N}$ is a chlorophyll component, with significant participation in increasing plant leaf area, which increases the efficiency of solar radiation interception and the photosynthetic rate, leading to plant physiologic effects, such as an increase in tillers, panicles and spikelets per panicle number, percentage of filled grains, grain number and size, being $N$ the main limiting factor for yield (Fidelis et al., 2011).

For the fertility management, nitrogen is one of the most influenced element in irrigated rice production systems. Nitrogen has an extremely complex dynamics due to the diversity of chemical forms, reactions and processes that this nutrient can be involved. $\mathrm{N}$ can be lost by leaching, volatilization and denitrification, reflecting directly on the lower efficiency (50$60 \%$ ) of the use of this nutrient (from fertilizers) for the culture (Lopes et al., 2013b). However, in order to obtain positive responses for $\mathrm{N}$ applications, appropriate management practices and the use of more efficient cultivars for $\mathrm{N}$ absorption and utilization should be taken into consideration.

$\mathrm{N}$ is a mobile nutrient in soil and its ionic form changes according to time, soil and climate. Sandy soils are characterized by a large amount of pores that enable rapid internal infiltration of water and nutrients in the soil profile. The nitrate formed by the nitrification process is subject to intense leaching in flooded and sandy soils (Fageria \& Baligar, 2005).

Thus, there is a need for research that enables the use of a fertilizer recommendation suited to sandy soils and regional conditions of Tocantins wetlands, so that this nutrient can be used rationally. The objective of this study was to evaluate the effect of five nitrogen doses in rice cultivars (Iraga-424 and Irga-423) grown on tropical lowland sandy soils.

\section{Material and Methods}

The study was conducted in an irrigated lowland under flood system at COPERJAVA (Mixed Cooperative of Araguaia Valley), in the municipality of Formoso do Araguaia-TO, Brazil, located at $11^{\circ} 50$ 'south latitude and 49³8' west longitude and altitude of $221 \mathrm{~m}$ with a topography with less than $0.05 \%$ of inclination, in a humic gleysol, during the 2012/2013 crop year.

The experiment was carried out in a randomized block design, in a $2 \times 5$ factorial with four repetitions, being two cultivars (Irga-424 and Irga-423) and five $\mathrm{N}$ doses $(30,60,90,120$ and 150 $\mathrm{kg} \mathrm{ha}^{-1} \mathrm{~N}$ ), applied as urea. Each experimental plot consisted of twenty-seven lines of $15 \mathrm{~m}$ in length, spaced $0.17 \mathrm{~m}$ between rows. The useful area consisted of the four central rows with two linear meters of length.

The type of planting adopted was a no-till system (seeding without tillage), in succession to soybean planting. The soil physical and chemical analysis are presented on Table 1.

The sowing and basic fertilization at planting were performed mechanically on November 15t, 2012, using $300 \mathrm{~kg} \mathrm{ha}^{-1}$ of the formulated 10.10 .30 to achieve the NPK requirement at planting. The topdressing (discounting the base $\mathrm{N}$ fertilization) consisted of $\mathrm{N}$ as urea and was divided in two applications, 
the first held upon the effective tillering (50\% of the dose) and the second at the panicle differentiation stage ( $50 \%$ of the dose). Thus, for the dose of $30 \mathrm{~kg}$ $\mathrm{N} \mathrm{ha}^{-1}$, no topdressing was made.

Table 1. Experimental area soil analysis, from 0-20cm, Formoso do Araguaia, TO, Brazil $-2012 / 0213$ crop year.

\begin{tabular}{|c|c|c|c|c|c|c|c|c|c|c|c|}
\hline $\mathrm{Ca}+\mathrm{Mg}$ & $\begin{array}{c}\mathrm{Al} \\
\mathrm{nOl}_{\mathrm{c}} \mathrm{C}\end{array}$ & $\mathrm{H}+\mathrm{Al}$ & $\begin{array}{r}\mathrm{T} \\
---\end{array}$ & K & $\begin{array}{c}P \\
g d m\end{array}$ & $\mathrm{MO}$ & $\mathrm{pH} \mathrm{CaCl} 2$ & $\begin{array}{c}\mathrm{V} \\
----\end{array}$ & Sand & Silt & Clay \\
\hline 3.7 & 0.0 & 1.8 & 7.0 & 37 & 48.5 & 25 & 5.1 & 75 & 81.5 & 1.3 & 17.2 \\
\hline
\end{tabular}

As phytosanitary treatments, three preemergent herbicide applications for weed control were applied, being the first for area desiccation and made using a mixture of glyphosate (2.0 L $\mathrm{h}^{-1}$ ) with methyl-metsulfurom (3.0 $\left.\mathrm{g} \mathrm{ha}^{-1}\right)$; the second was applied one day before planting, for weed control, with glyphosate (1.8 $\left.\mathrm{L} \mathrm{ha}^{-1}\right)$; and the third with three days after planting, with a mix of Glomazona (0.5 mL h-1), Oxifluorfem $\left(0.6 \mathrm{~L} \mathrm{~h}^{-1}\right)$ and glyphosate $\left(1 \mathrm{~L} \mathrm{ha}^{-1}\right)$. As post-emergence, a mixture of bispyribac-sodium (100 $\left.\mathrm{mL} \mathrm{ha}^{-1}\right)$ and methyl-metsulfuron (3 $\mathrm{g} \mathrm{ha}^{-1}$ ) was used. For a better pesticide distribution on leaf surface and less drift, Adjuvanteß at a dose of $40 \mathrm{~L} \mathrm{ha}^{-1}$ was applied.

Three inseticides and fungicides application were held. The first was realized at November, 22, 2012 with Cioermetrin $(100 \mathrm{~mL}$ $\mathrm{ha}^{-1}$ ) for larvae control and with the insecticide Tebuconazole $\left(0.75 \mathrm{~L} \mathrm{~h}^{-1}\right)$ for rice blast neck preventive control; the second application was carried out two months later using the insecticide acephate (1 $\left.\mathrm{kg} \mathrm{ha} \mathrm{ha}^{-1}\right)$ with the fungicides tricyclazole $\left(0.3 \mathrm{~kg} \mathrm{ha}^{-1}\right)$ and Tebuconazole $(0.75$ $\left.\mathrm{L} \mathrm{h}^{-1}\right)$. The third application occurred 95 days after planting, using Acephate (1 kg ha-1) and cypermethrin (100 $\left.\mathrm{mL} \mathrm{ha-}^{-1}\right)$ inseticides with the fungicides azoxystrobin $\left(0.4 \mathrm{~L} \mathrm{~h}^{-1}\right)$, tricyclazole $(0.3$ $\mathrm{kg} \mathrm{ha}^{-1}$ ) and Tebuconazole (0.75 $\mathrm{L} \mathrm{ha-}^{-1}$ ) for neck blast preventive control.

The evaluated characteristics were grain yield - clean grain with $14 \%$ of moisture in $\mathrm{kg} \mathrm{ha}^{-1}$; number of panicles per square meter $\left(\mathrm{m}^{2}\right)$, counting panicles in one square meter in a plot useful area; hundred grain mass - mass of a sample with hundred healthy grain per plot; plant height - measured from soil surface to the central panicle apex; nitrogen content - 100 flag leaves, which is the last leaf to emerge for each culm, per plot, were submitted to oven dry at $65^{\circ} \mathrm{C}$ for 72 hours and were ground into a fine powder and the $\mathrm{N}$ was determined according to Kjeldahl method; and total chlorophyll index - measured at the middle third of the plant, in a central part of the leaf blade in 10 plants per plot, using the ClorofiLOG ${ }^{\circledR}$ equipment model CFL 1030, expressed in CFI (Chlorophyll Falker Index).

Data were submitted to regression and variance analysis using $\mathrm{F}$ test at $5 \%$ of probability. For variables that presented second and third degree responses, the differential calculations were used to estimate the inflection points and the respective $Y$ value. For parameters that presented linear responses, the criteria of $100 \%$ of the quantitative treatment was used for the maximum response, using the SISVAR (Ferreira, 2008) software.

\section{Results and Discussion}

Linear response to plant height and an increase in plant size with the use of nitrogen fertilization was observed for both cultivars (Figure 1).

It is possible to observe that the cultivar Irga-424 presented higher means for plant height in all studied doses, when compared to Irga-423. Even with the use of higher $\mathrm{N}$ doses, no lodging was observed for both cultivars, effect that is related on literature, since higher $\mathrm{N}$ doses can lead to a higher tiller and new leaves, resulting in lodging (Buzetti et al., 2006).

For total chlorophyll index, a linear response to increasing doses of nitrogen fertilization was observed, which was expected, since the chlorophyll content is positive correlated with leaf nitrogen content and this nutrient is part of the chlorophyll molecule (Figure 2).

According to Taiz \& Zeiger (2013), chlorophylls, typyical pigments of photosyntetic organisms, are one of the most important chelates in nature and have a complex porphyrin ring structure type (four $\mathrm{N}$ atoms forming bridges 


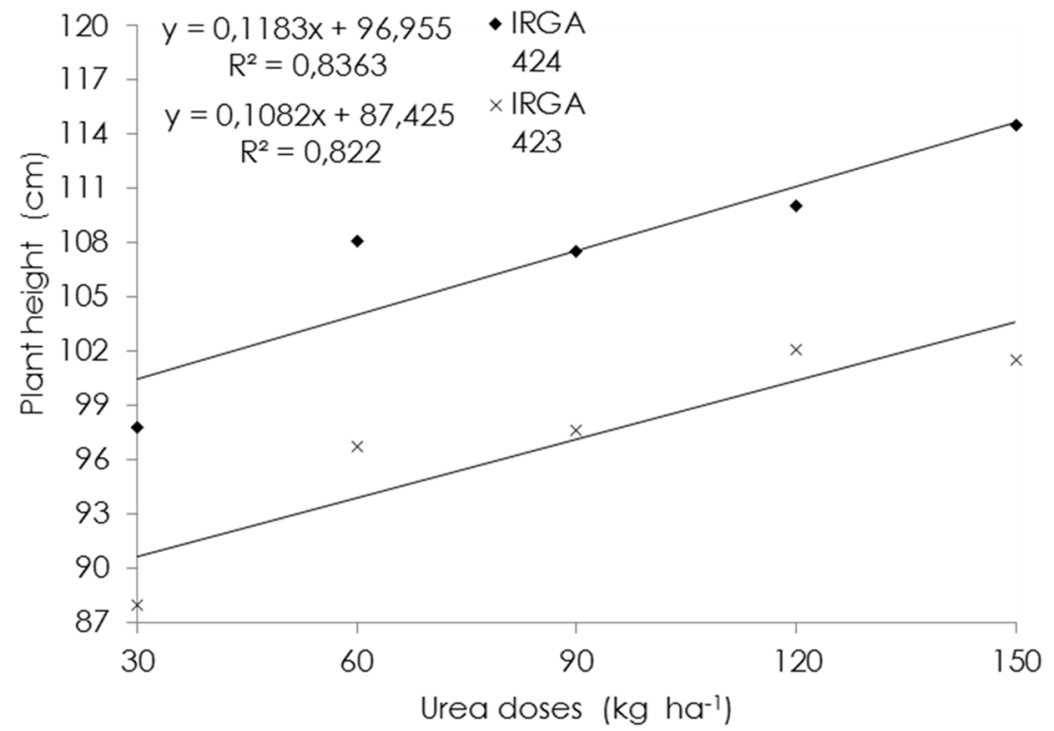

Figure 1. Plant height (cm) for two rice cultivars (Irga-424 and Irga-423) according to nitrogen doses applied as urea, obtained from the experiment of "Nitrogen doses in rice grown in a tropical lowland", Formoso do Arguaia - TO, Brazil for the 2012 and 2013 crop years. ${ }^{*}$ and ${ }^{* *}$ : significant at $5 \%$ and $1 \%$ of probability, according to $\mathrm{F}$ test.

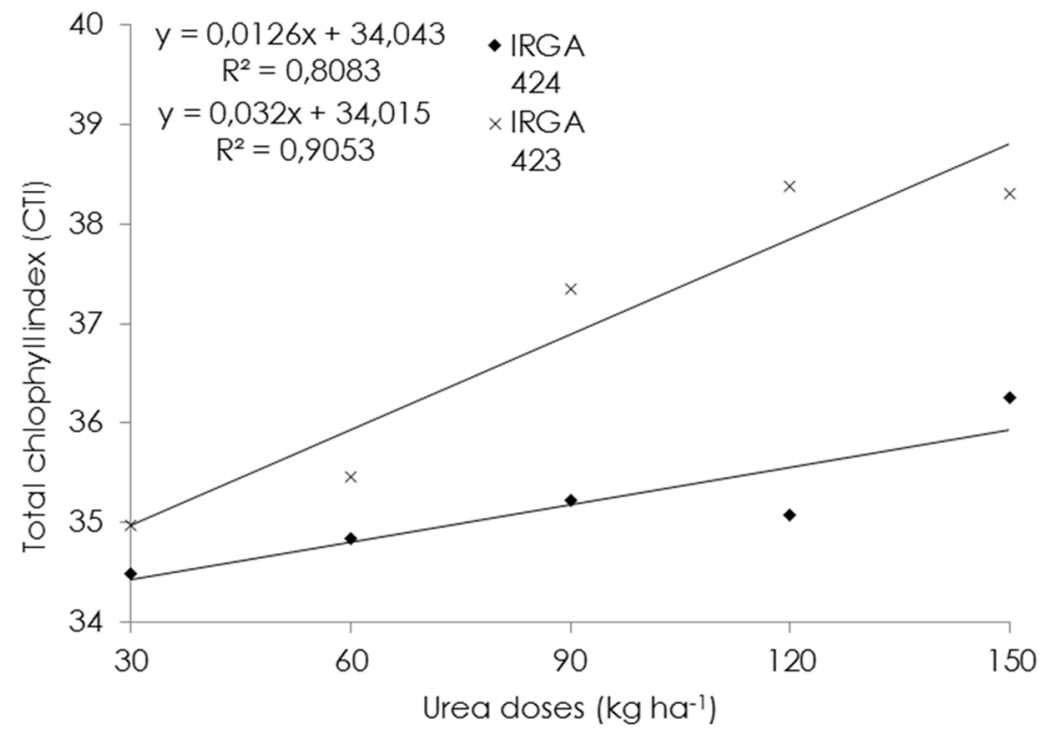

Figure 2. Variation for chlorophyll total index (CTI) for two rice cultivars (Irga-424 and Irga-423) according to nitrogen doses applied as urea, obtained from the experiment of "Nitrogen doses in rice grown in a tropical lowland", Formoso do Arguaia - TO, Brazil for the 2012 and 2013 crop years. ${ }^{*}$ and ${ }^{* *}$ : significant at $5 \%$ and $1 \%$ of probability, according to F test.

with a coordinated $\mathrm{Mg}$ atom in the center) and a long tail of hydrophobic hydrocarbons that anchors the photosynthetic membranes. Silva et al., (2007) also observed a linear response to increased nitrogen fertilization in relation to chlorophyll content. It is possible to observe that the cultivar Irga-423 presented higher chlorophyll content with the application of different doses when compared to the cultivar Irga-424, and this fact can be associated with the constant tiller emission observed for the cultivar Irga-424 throughout its cycle.

Another point that can be related to this characteristic is that the cultivar Irga-424 is indicated to regions with lower temperatures and less photosynthetic intensity.

Analyzing the $\mathrm{N}$ content in the leaves, it is possible to observe a linear response to both cultivars (Figure 3). 


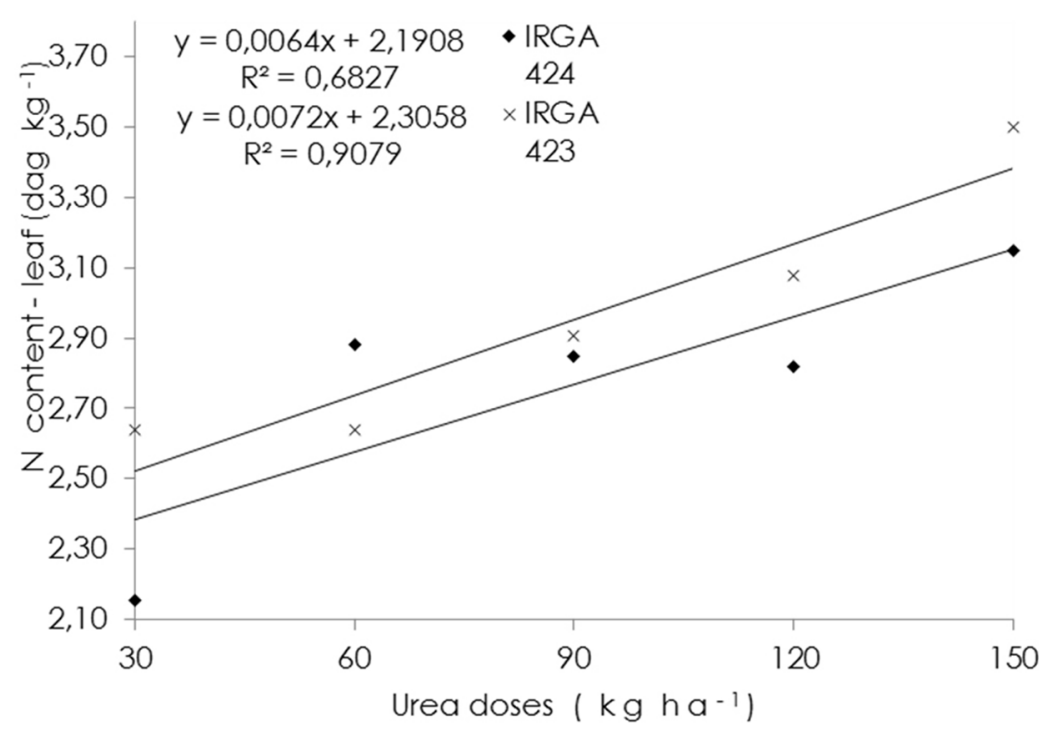

Figure 3. $\mathrm{N}$ content in leaves (dag $\mathrm{kg}^{-1}$ ) for two rice cultivars (Irga-424 and Irga-423) according to nitrogen doses applied as urea, obtained from the experiment of "Nitrogen doses in rice grown in a tropical lowland", Formoso do Arguaia - TO, Brazil for the 2012 and 2013 crop years. ${ }^{*}$ and ${ }^{* *}$ : significant at $5 \%$ and $1 \%$ of probability, according to $\mathrm{F}$ test.

The rice plant has a high nitrogen demand, which is the main nutrient responsible for the crop growth, development and consequently, yield. It is important to observe that both cultivars are well nourished from the dose of $60 \mathrm{~kg} \mathrm{ha}^{-1}$, with an adequate nutrient level. Silva et al., (2012), analyzing macronutrient contents in different rice cultivars, observed adequate levels ranging from 1.24 to $1.45 \mathrm{dag} \mathrm{kg}^{-1}$, and the author explained that this variation is due to cultivar differences.

As well as the chlorophyll content, the cultivar Irga-423 also presented higher $\mathrm{N}$ content in the plant when compared to Irga-424. Since nytrogen is one of the most important nutrients in chlorophyll, it is expected that these variables show similar responses, as shown by Mattje et al., (2013).

For the number of panicles per square meter $\left(\mathrm{m}^{2}\right)$, the regression coeficient for both cultivars were not significant. Thus, we can conclude that cultivars were not affected by nitrogen fertilization and presented similar tillering capacity with different nitrogen doses (Figure 4).

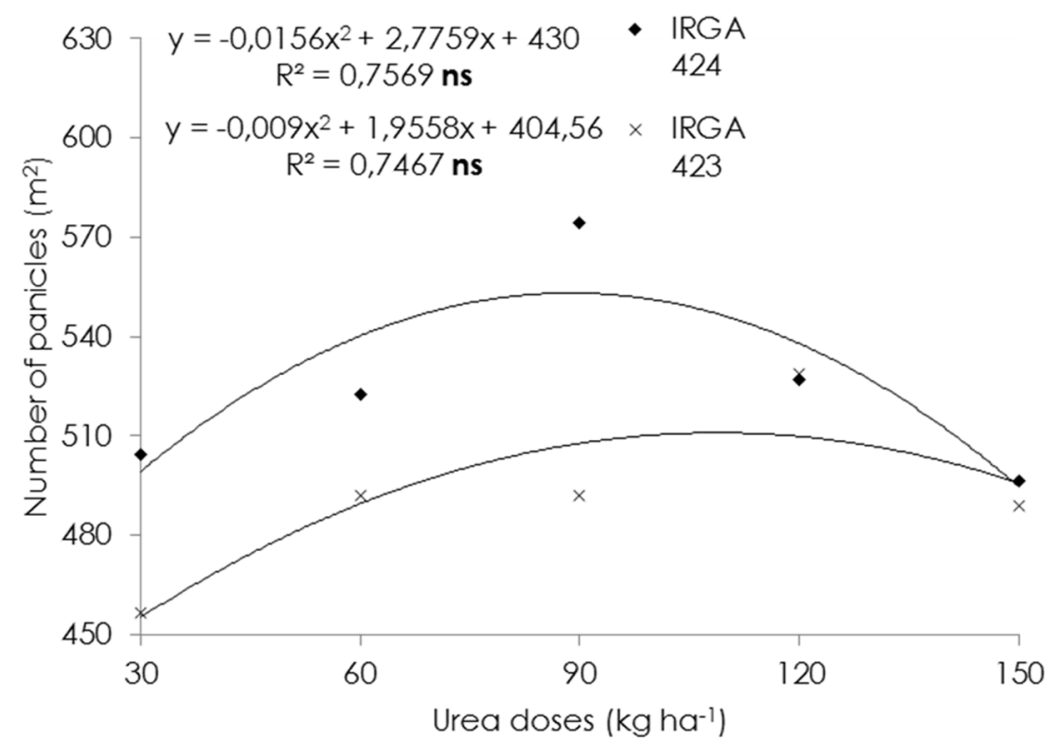

Figure 4. Number of panicles $\left(\mathrm{m}^{2}\right)$ for two rice cultivars (Irga-424 and Irga-423) according to nitrogen doses applied as urea, obtained from the experiment of "Nitrogen doses in rice grown in a tropical lowland", Formoso do Arguaia - TO, Brazil for the 2012 and 2013 crop years. ${ }^{*}$ and ${ }^{* *}$ : significant at $5 \%$ and $1 \%$ of probability, according to $\mathrm{F}$ test. 
The lack of response for this character is probably related to the rice planting, that was done in succession to soy, which is a specie from the Fabaceae family and is able to realize the biological nytrogen fixation (BNF), contributing to soil nutrient content. According to Calegari \& Ralich (2011), the main advantages of the rice cultivation with sowbean rotation is that are the benefits of the rotation per se, the production of a higher quality straw and mainly the use of nytrogen that was fixed by the specie. Another factor that could influence the nitrogen fertilization increment lack of response is the organic matter in the soil, which is about $25 \mathrm{mg}$ $\mathrm{dm}^{-3}$. According to Malavolta et al., (2011), this content is considered as a medium level. The first nitrogen fertilizaition ( $30 \mathrm{ha}^{-1}$ of $\mathrm{N}$ ) in addition to the organic matter (OM) probably provided the required $\mathrm{N}$ amount to meet the crop requirements. Similar results were observed by Meira et al., (2005) with their studies of rice cultivars submitted to four doses of $\mathrm{N}\left(0,50,100\right.$ and $\left.150 \mathrm{~kg} \mathrm{ha}^{-1}\right)$, that also observed a lack of response for panicle number according to nitrogen fertilization and the authors concluded that the soil provided the necessary $\mathrm{N}$ anount to meet the crop demand.

For hundred grain mass, no response was observed according to nitrogen ferlization increment. No significant adjustment was observed for the equations and the regression and the determination coeficients were not signifficant for both cultivars (Figure 5).

Machado (1994) explains that the grain

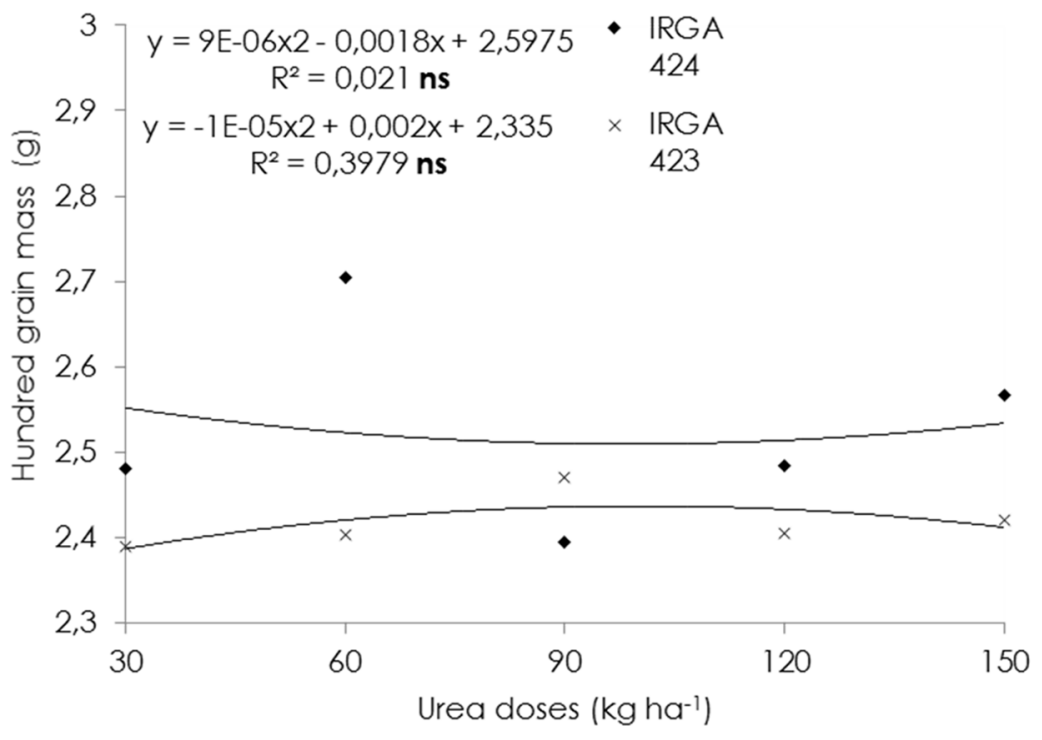

Figure 5. Hundred grain mass (g) for two rice cultivars (Irga-424 and Irga-423) according to nitrogen doses applied as urea, obtained from the experiment of "Nitrogen doses in rice grown in a tropical lowland", Formoso do Arguaia - TO, Brazil for the 2012 and 2013 crop years. ${ }^{*}$ and ${ }^{* *}$ : significant at $5 \%$ and $1 \%$ of probability, according to $\mathrm{F}$ test.

mass is a stable varietal character, that is not influenced by environment but by the skin size, which is determined two weeks prior to anthesis, and also by the caryopsis development, which is related to carbohydrates translocation in the first seven days to fill the rice towards its length and for the successive seven days to improve plant width and thickness.

Thus, the lower $\mathrm{N}$ dose associated with soil organic matter content were able to supply the crop demand. Hernandes et al., (2010) also did not observed an increase in a hundred grain mass variable according to nitrogen fertilization.
In relation to grain yield, nitrogen doses were adjusted in a quadratic function and the maximum economic efficiency was based on $90 \%$ of the maximum technical efficiency (Figure $6)$.

Thus, the Irga-424 cultivar achieved the maximum yield with the $\mathrm{N}$ dose of $96.72 \mathrm{~kg} \mathrm{ha}$ ${ }^{-1}$ and the cultivar Irga-423 with the $\mathrm{N}$ dose of $126.38 \mathrm{~kg} \mathrm{ha}^{-1}$. A yield decrease was observed when higher doses were used.

Irga-424 presented the higher mean for yield $\left(7800 \mathrm{~kg} \mathrm{ha}^{-1}\right)$ with the lower $\mathrm{N}$ dose (996 kg ha-1) and Irga-423 achieved the yield of 
$5860 \mathrm{~kg} \mathrm{ha}^{-1}$ with the higher dose (126 kg ha-1), so it is possible to recommend this option for rice growers that do not want do have more expenses with fertilization. Lopes et al., (2013a) observed a yield of $8098 \mathrm{~kg} \mathrm{ha}^{-1}$ when $105 \mathrm{~kg} \mathrm{ha}^{-1}$ of $\mathrm{N}$ was used, with a higher yield than the estimated for Tocantins state, which is 80 bags of $60 \mathrm{~kg} \mathrm{ha}^{-1}$.

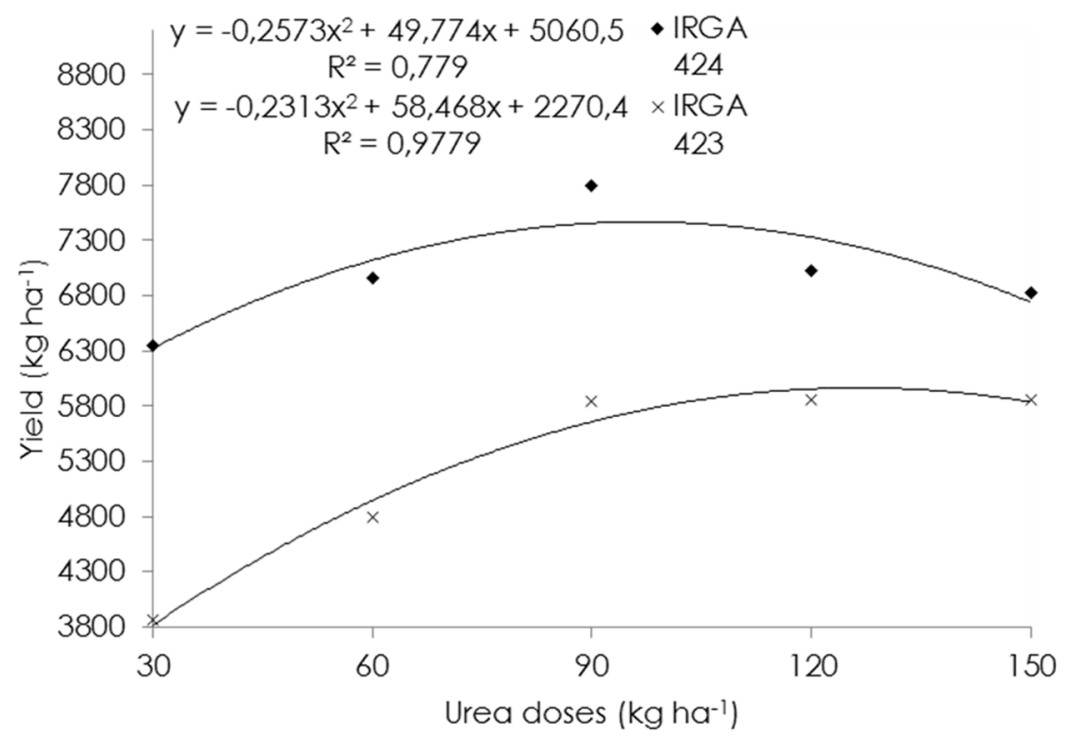

Figure 6. Yield variation ( $\mathrm{kg} \mathrm{ha}^{-1}$ ) for two rice cultivars (Irga-424 and Irga-423) according to nitrogen doses applied as urea, obtained from the experiment of "Nitrogen doses in rice grown in a tropical lowland", Formoso do Arguaia - TO, Brazil for the 2012 and 2013 crop years. * and **: significant at $5 \%$ and $1 \%$ of probability, according to $\mathrm{F}$ test.

\section{Conclusions}

Cultivars responded to nitrogen fertilization, achieving the maximum yield with the $\mathrm{N}$ application in a dose of 96.72 and 126.38 $\mathrm{kg} \mathrm{ha}^{-1}$ for Irga 424 and Irga 423, respectivelly.

The grain yield was 7467.66 and 5965.28 $\mathrm{ha}^{-1}$ for Irga 424 and Irga 423, respectivelly.

The dose of $150 \mathrm{~kg} \mathrm{ha}^{-1}$ of $\mathrm{N}$ lead to higher vales of plant height, total chlorophyll and hundred grain mass.

The application of nitrogen doses above $60 \mathrm{~kg} \mathrm{ha}^{-1}$, in soils with medium organic matter content, can result in plants with an adequade $\mathrm{N}$ leaf content, even in sandy soils.

\section{References}

Buzetti, S., Bazanini, G.C., Freitas, J.G., Andreotti, M., Arf, O., Sá, M.E., Meira, F.A. 2006. Resposta de cultivares de arroz a doses de nitrogênio e do regulador de crescimento cloreto de clormequat. Pesquisa Agropecuáia Brasileira 14: 1731-1737.

Cancellier, E.L., Barros, H.B., Kischel, E., Gonzaga, L.A.M., Brandão, D.R., Fidelis, R.R. 2011 . Eficiência agronômica no uso de nitrogênio mineral por cultivares de arroz de terras altas. Revista Brasileira de Ciências Agrárias 6: 650 - 656.
Calegari, A., Ralich, R. 2007. Uso adequado de plantas de cobertura, rotação de cultura e seus benefícios no sistema de plantio direto. Revista Plantio Direto 97: 13 -16.

Fageria, N.K., Baligar, V.C. 2005. Enhancing nitrogen use efficiency in crop plants. Advances in Agronomy 88: 97-185.

Ferreira, D.F. 2008. SISVAR: Um programa para análise e ensino de estatística. Revista Symposium 6: 36-41.

Fidelis, R.R., Kischel, E., Machado, A.F.L., Cancellier, E.L., Passos, N.G. 2012. Eficiência no uso de nitrogênio de genótipos de arroz em solos de várzea irrigada. Revista Verde 7: 264-272.

Fidelis, R.R., Rodrigues, A.M., Silva, G.F., Barros, H.B., Pinto, L.C., Aguiar, W.S. 2011 .Eficiência do uso de nitrogênio em genótipos de arroz de terras altas. Pesquisa Agropecuária Tropical 42: 124-128.

Hernandes, A., Buzetti, S., Andreotti, M., Arf, O., Sá, M.E. 2010. Doses, fontes e épocas de aplicação de nitrogênio em cultivares de arroz. Ciências Agrotecnologia 34: 307-312.

Lopes, M.B.S., Sousa, S.A., Nascimento, I.R., Fidelis, R.R. 2013a. Resposta de cultivares de arroz á adubação nitrogenda em solos arenosos de várzea tropical. Revista Verde 8: 86 - 92. 
Lopes, R.A., Buzetti, S., Teixeira Filho, M.C.M., Benett, C.G., Arf, M.V. 2013b. Doses, fontes e épocas de aplicação de nitrogênio em arroz de terras altas cultivado em sistema de semeadura direta. Revista Caatinga 26: 79-87.

Machado, J. R. 1994. Desenvolvimento da planta e produtividade de grãos de populações de arroz (Oryza sativa L.) irrigado por inundação em função de épocas de cultivo. UNESP, Botucatu, Brasil. 237p.

Malavolta, E., Pimentel, G.F., Alcarde, J.C. 2011. Adubos \& Adubações. Nobel, São Paulo, Brasil. Nobel, 200p.

Mattje, V.M., Fidelis, R.R., Aguiar, R.W.S., Brandão, D.R., Santos, M.M. 2013. Avaliação de cultivares de arroz em doses contrastante de nitrogênio em solos de várzea irrigada. Journal of Biotechnology and Biodiversity 4: $126-133$.

Meira, F.A., Buzetti, S., Freitas, J.G., Arf, O., Sá, M. E. 2005. Respostas de dois cultivares de arroz à adubação nitrogenada e tratamento foliar com fungicidas. Acta Scientiarum Agronomy 27: 9195.

Silva, L.S., Bohnen, H., Marcolin, E., Macedo, V.R. M., Pocojeski, E. 2007. Resposta a doses de nitrogênio e avaliação do estado nutricional do arroz irrigado. Revista Brasileira de Agrociência 13: 189-194.

Silva, L.S., Pocojeski, E., Ceretta, C.A., Bundt, A.C., Kaefer, S., Marchesan, E. 2012. Teores de macronutrientes em cultivares de arroz irrigado de acordo com a parte da planta analisada e do estádio de desenvolvimento. Revista Ceres 59: 544-549.

Taiz, L., Zeiger, E. 2013. Fisiologia vegetal. Artmed, Porto Alegre, Brasil. 719 p. 